\title{
Análise do conhecimento sobre o Papilomavírus Humano, de usuários do Centro de Saúde de Brasília - DF
}

\author{
Analysis of knowledge about the Human Papillomavirus of users of \\ the Brasilia Health Center - DF
}

\author{
Bárbara Lucas Pereira ${ }^{1}$, Aline Kelen Vesely Reis ${ }^{2}$ \\ ${ }^{1}$ Graduanda em Biomedicina da Universidade Paulista (UNIP), Brasília-DF, Brasil. ${ }^{2}$ Mestre em \\ Epidemiologia de Saúde Pública pela Fundação Oswaldo Cruz (FIOCRUZ), Brasília-DF, Brasil.
}

\begin{abstract}
Resumo
Introdução - O Papilomavírus humano, conhecido como HPV, é um vírus que pertence à família Papovavírus ou Papovaviridae, que replica-se no núcleo de células epiteliais escamosas e que afeta tanto homens quanto mulheres. A infecção pelo HPV é uma das infecções sexualmente transmissíveis mais frequentes no mundo, a maioria das infecções são assintomáticas ou não aparentes. Outras podem apresentar-se sob a forma de lesões exofíticas, os chamados condilomas acuminados, verrugas genitais ou cristas de galo. Objetivo - Analisar o conhecimento sobre o Papilomavírus humano dos usuários atendidos no Centro de Saúde de Brasília-DF. Material e Métodos - O presente trabalho constitui-se de um estudo transversal analítico, com a participação de 60 usuários escolhidos aleatoriamente, de ambos os sexos, com idade acima de 18 anos, onde realizavam atendimento no Centro de Saúde de Brasília -DF, durante o período de novembro de 2017. O estudo baseou-se na aplicação de um questionário estruturado com questões objetivas associadas ao conhecimento sobre o HPV. Resultados - Os resultados analisados mostraram que os 60 usuários participantes já tinham ouvido falar sobre o HPV, sendo que $63 \%$ dos respondentes tinham idade entre 18 a 27 anos e $70 \%$ eram do sexo feminino. Entre a principal via de transmissão, $100 \%$ relataram por contato sexual, e apenas 33\% disseram que o HPV nem sempre apresenta sinais ou sintomas. Sobre a vacinação $53 \%$ aceitariam ser vacinados, e $40 \%$ associaram a higiene pessoal como uma medida de prevenção contra o vírus. Conclusão - Embora o Brasil tenha inserido em seu Programa Nacional de Imunização a vacina quadrivalente contra o vírus HPV e empreendido campanha de esclarecimento da população, ainda há um déficit de desconhecimento da população sobre o tema.
\end{abstract}

Palavras-chave: Papiloma Vírus, IST, Centro de Saúde, Saúde Pública.

\begin{abstract}
Introduction - The human papillomavirus, known as HPV, is a virus that belongs to the family Papovaviruses or Papovaviridae, which replicates in the nucleus of squamous epithelial cells and affects both men and women. HPV infection is one of the most common sexually transmitted infections in the world; most infections are asymptomatic or non-apparent. Others may present as exophytic lesions, so-called condylomata acuminata, genital warts, or ridge crests. Objective - To analyze the knowledge about the human Papillomavirus of the users served at the Health Center of Brasilia-DF. Material and Methods - The present study is a cross-sectional, analytical study, with the participation of 60 randomly selected users of both sexes, aged over 18 years, who were attending the Brasilia Health Center -DF during the period of November 2017. The study was based on the application of a structured questionnaire with objective questions associated with knowledge about HPV. Results - The results showed that 60 participants had heard about HPV, 63\% of respondents were between 18 and 27 years old and $70 \%$ were female. Among the main transmission route, $100 \%$ reported on sexual contact, and only $33 \%$ said that HPV does not always show signs or symptoms. About vaccination $53 \%$ would accept to be vaccinated, and $40 \%$ associated personal hygiene as a preventive measure against the virus. Conclusion - Although Brazil has inserted in its National Program of Immunization the quadrivalent vaccine against the virus HPV and undertaken campaign of enlightenment of the population, there is still a lack of knowledge of the society on the subject.
\end{abstract}

Key words: Papilloma Virus, IST, Health Center, Public Health. 
ISBN: 978-65-80968-15-2

Galoá $\{$ Este trabalho foi publicado utilizando o Galoá proceedings https://proceedings.science/p/113750?lang=pt-br 